\title{
MODULAR ROBOT DESIGN AND APPLICATION FOR CHILDREN'S DEVELOPMENT IN MECHATRONICS AND AUTOMATION
}

\author{
Erhan Kayaalp $^{1 \star}$, Nihat Akkuş ${ }^{2}$, İsmail Temiz ${ }^{3}$ \\ ${ }^{1}$ Marmara Üniversity, TURKEY, erhan.kayaalp@marun.edu.tr \\ ${ }^{2}$ Prof. Dr. Marmara University, TURKEY, nihat.akkus@marmara.edu.tr \\ ${ }^{3}$ Assist. Prof. Dr. Marmara University, TURKEY, itemiz@marmara.edu.tr \\ ${ }^{*}$ Corresponding author
}

\begin{abstract}
The effect of activity sets in the education of primary students in science class was examined using modular automation sets in this study. It is aimed to understand their scientific process skills and motivation towards other integrated technologies. The study group of this research consists of the 4 th grade students of a private school on the Anatolian side of Istanbul.

Students were given an activity to carry out within the scope of this research by using these automation sets which were procured by the school. A model from the set was designed by the students and the students were requested to make improvements on this model with the guidance and directions of their teacher. The changed parts in the improved model were designed and printed out from a 3D printer. A touch sensor was installed on the finished model and the program software was reconstructed. Finally the students in the study group were subjected to a comprehension test and the results were evaluated.

The result of the study shows that students have positive inclination towards building and programming their own designs. Also the use of visual blocks in the system software has shown an increase in student attention and it's been observed that this contributes to easier understanding of the software by the students.
\end{abstract}

Keywords: Modular toy, Mechatronic activity, Modular application set, 3D Printer, Visual programming

\section{INTRODUCTION}

The rapid advancements in science and technology drive countries of the world towards various economic and social developments while making it a necessity to create new education systems.

In order to be able to keep up with these technological advancements, these countries make plans, improve their infrastructures with all of their available resources and question their existing education systems to create a better qualified workforce. (Bilisim Surası, 2003). 
The aim of this study is advancing the fundamental science and technology knowledge of 4th grade students by carrying out an educational activity with a ready automation set acquired from a vendor as well as enabling these students to make improvements on the given automation set with their improved fundamental knowledge.

In this context, a group of students were trained and put to work on the experiment set. Later, the students were issued a test to measure the success of the education program and were requested to make improvements on the model.

Within this scope, the students are expected to have a robotic product as an end result by coming up with creative solutions to the problems that are suited for the process.

\section{EXPERIMENT SET DESIGN}

Ready components that are currently available for sale were chosen for the education robot design. In this context, Fischertechnik Robo LT robot education set was procured and used for our study. This ready robotic system contains the hardware listed below.

Table 1. Robot set's contents and technical properties

\begin{tabular}{|ll|}
\hline Number of Parts & 200 pieces \\
\hline Programmable Block & Processor -8 bit \\
& USB connection \\
& 3 input, sensör input \\
& 2 output, motor output \\
\hline Sensors & 2 touch sensors \\
& 1 phototransistor sensor \\
Motors & 1 XS Motor (9VDC ) \\
\hline
\end{tabular}

\subsection{Sample model design with ready robot education set}

First, automated fan model is selected from the models that come with the education set and the sample model is designed with the hardware pieces included within by following the steps below. 1 phototransistor sensor, 1 motor, 1 lens tip lamp and various assembly materials are used for building the model being designed. The system functions when the beam of light formed between the sensor and the light source is obstructed by an object.

Design assembly stages can be completed by following the steps below.

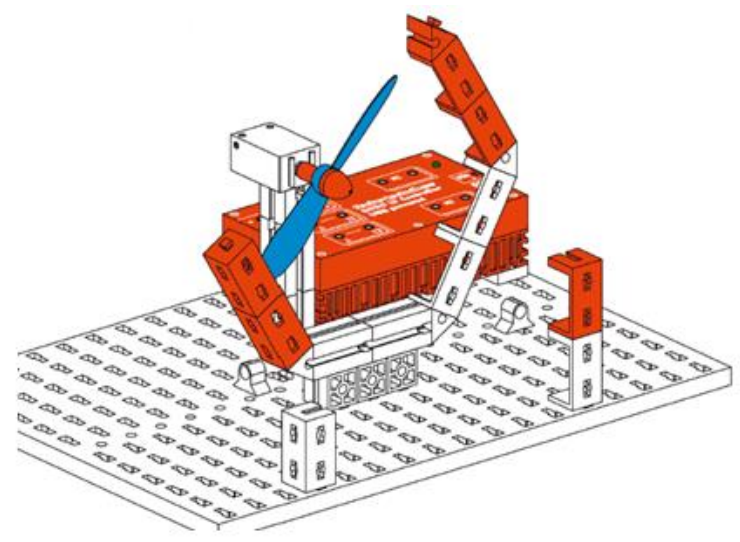

Figure 1A. Assembling the pieces 


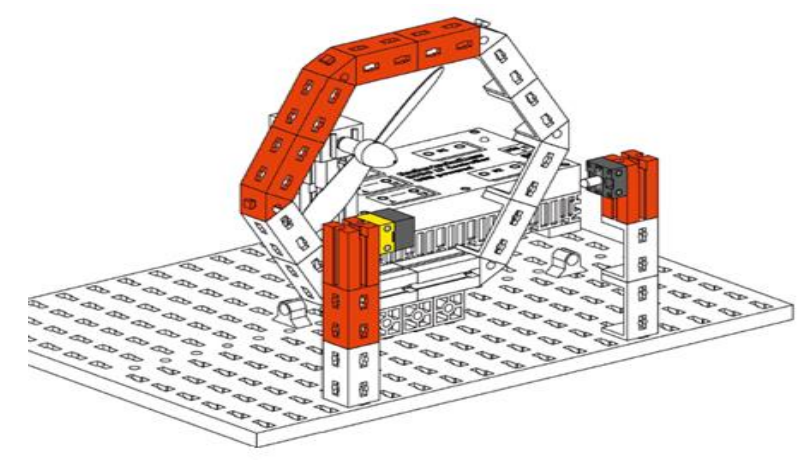

Figure 1B. Assembling the pieces

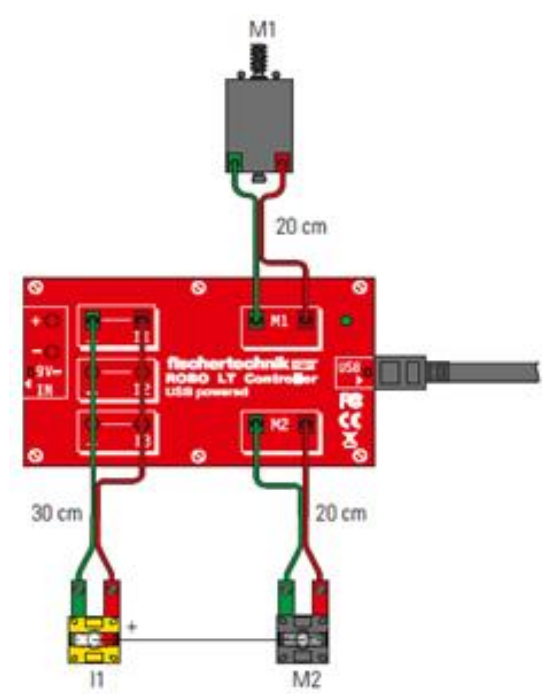

Figure 1C. The connection of sensor and motor on the control unit

\subsection{Programming of the designed system with a visual software.}

Taking into consideration the age and level of education of students, an easy-to-use, ready software was used. For that reason, a software that operates based on visual software principles was chosen for the programming of the automation system. The programming in this software is done by means of programming blocks and each block is responsible for one of the robot's motions. After the program is started, the motors, sensors and other components can be seen visually on the interface and the program is configured easily with the drag-and-drop method. The schematic flow diagram and visual software of the program can be seen in figure 2.
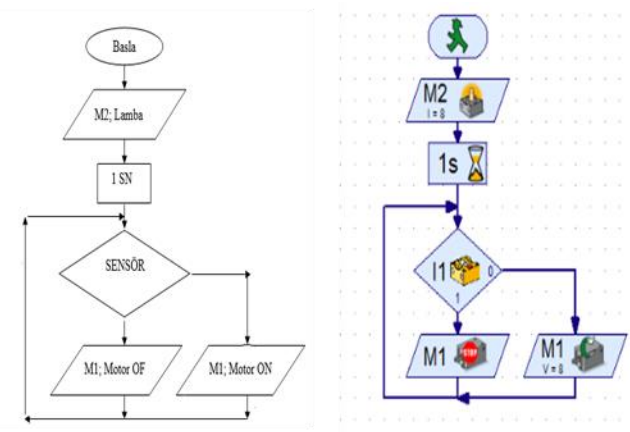

Figure 2. The flow diagram and visual software of the program.

15 students, who participated in this research, were given a test to complete at the end of the activities. According to the findings in table 2, a large part of the students have never used an education set like this before and again large part of them have expressed a desire to create their own designs and program them. Students have given high rate of correct answers to questions regarding the algorithm. 
IJASOS- International E-Journal of Advances in Social Sciences, Vol. III, Issue 9, December 2017

Table 2. Robot set and results of the algorithm test.

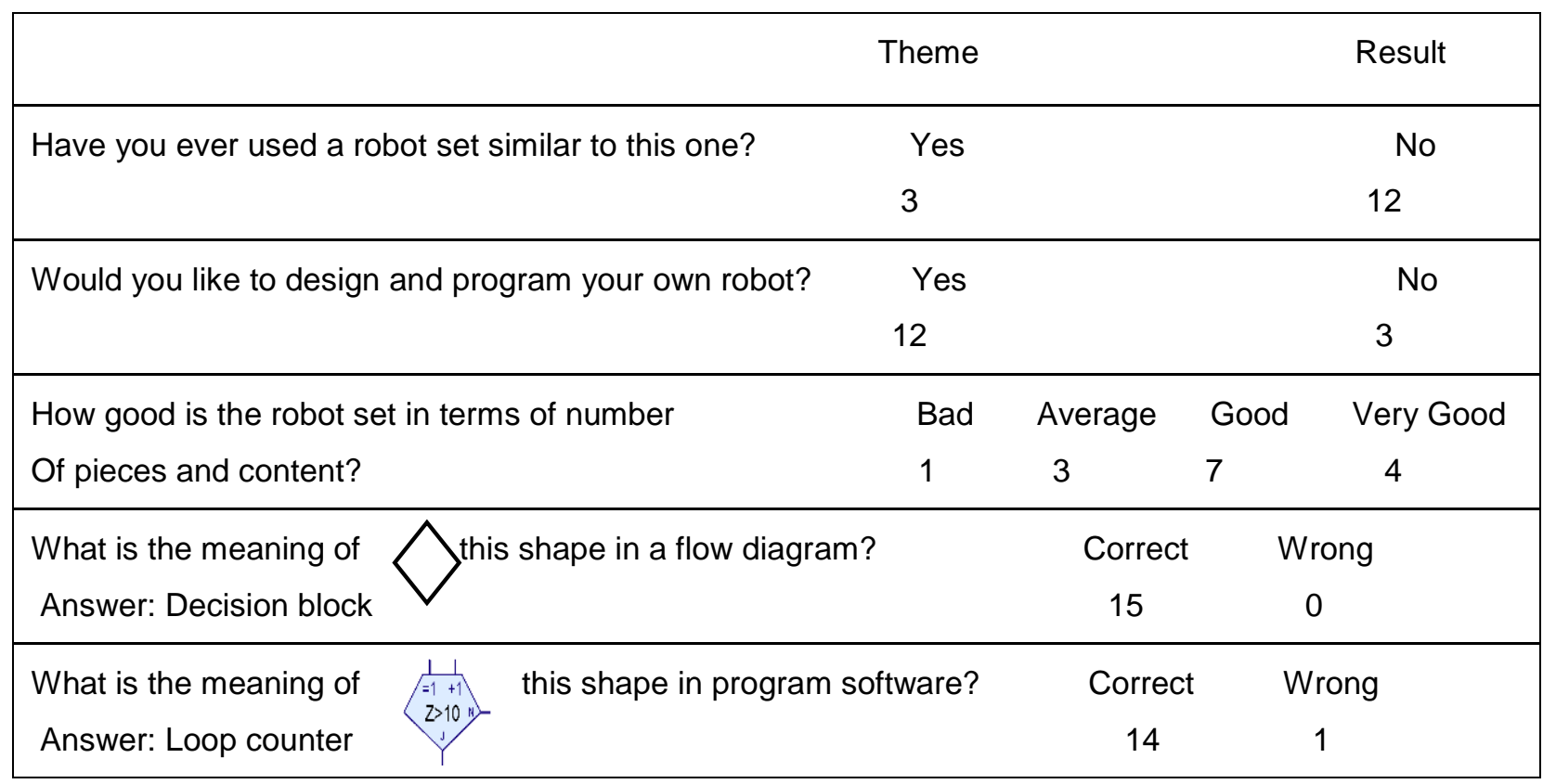

According to conclusions inferred from the meeting with the class teacher, the students appear to be pleased with the activities they have performed and they have fully adopted and internalized the work they have accomplished. Also, with help of the applications, it's started that the students have shown increased interest in the Science and Technology subject.

\section{IMPROVEMENT OF THE DESIGN}

We've recently begun to see a lot of automation sets around. These sets, as important as they are for model design and introduction to programming, are insufficient in terms of number of pieces. Many people have preferred to use 3D printers to print model parts and create their own designs. (Bas and Yapıcl, 2015).

In this research, results of the test applied on the potential subject students have been analyzed and examined. As a result of the study, it's been concluded that the students have grasped the automated fan system and the class teacher has conveyed her expectations that the system should be improved. At this point, the students have mainly expressed that the airflow speed generated by the fan is insufficient. After the evaluations, the fan was determined to be lacking in power and the students were directed to make improvements on the fan. Following the discussion on the subject, the students have reached the conclusion that using the fan seen in figure $3 \mathrm{C}$ instead of the fan seen in figure $3 \mathrm{~B}$ would generate greater airflow speed. Based on this conclusion, a design for the suggested fan measurements was created as seen in figure $3 \mathrm{~A}$, printed from a 3D printer and integrated into the system.

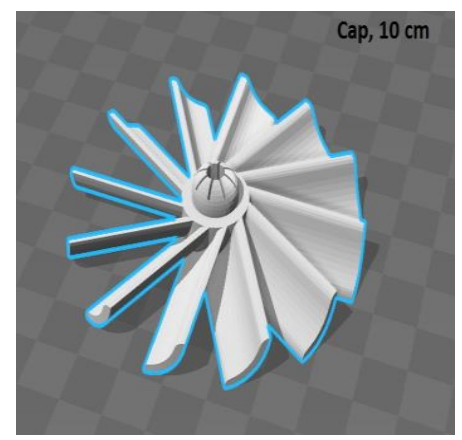

Figure 3A. 3D view of the improved fan 


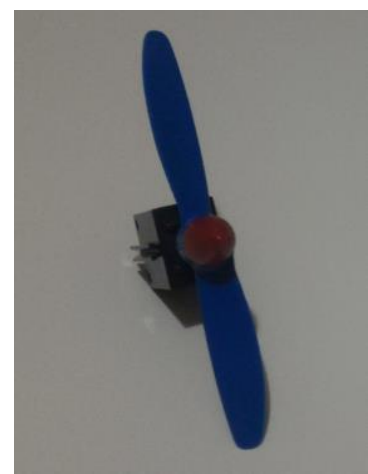

Figure 3B. Previous fan

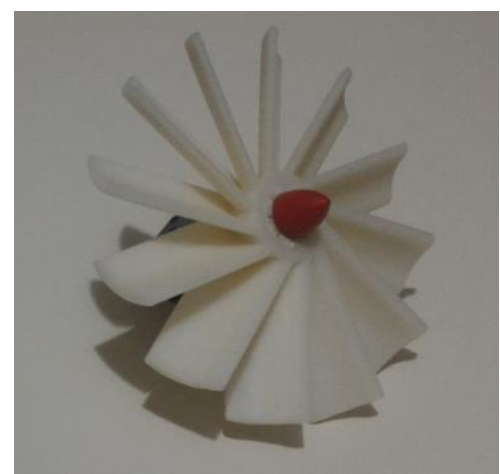

Figure 3C. 3D print- out of the improved fan

After the system's fan has been changed, a touch sensor is installed on the design with directions from the teacher. It will be possible for the system to function only if the touch sensor, which is added as a security measure, is activated. The new design after the installation of the fan and the sensor is shown in figure 4.

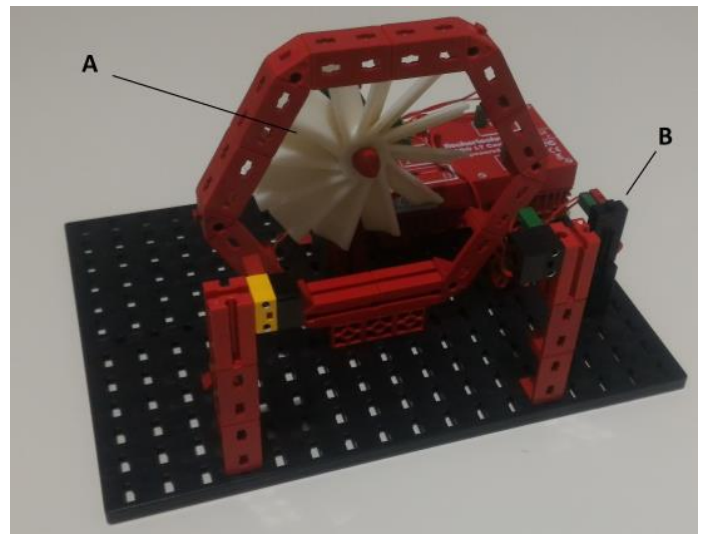

Figure 4. The new appearance of the design with the addition of the fan (A), and the touch sensor (B)

The system has also been expanded in terms of algorithm. After all the additions have been made, the programming of the designed model is shown in figure 5.

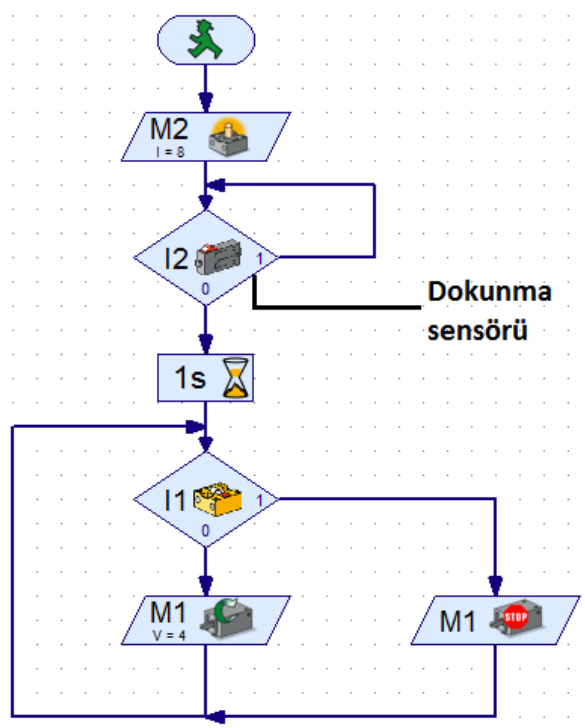

Figure 5. The reprogramming of the designed model 


\section{DISCUSSION AND CONCLUSION}

This study features usage of a ready automation set and examination of experimental activities. The effects of the activities on students' success, their attitude towards the subject and their motivation towards the science and technology class is studied. The study group of the research consists of 4th grade students attending at a Private School in the Küçükyalı district of Istanbul. The group is comprised of 15 students.

Ready automation sets were purchased for this project, provided for the students' use and their projects were examined. With the help of these projects, the aim is to enable students to design similar projects, gain control over them and learn the subject via computer aided education.

A comprehension test was issued to the participant students at the end of the project, the results of which were shown in Table 2.

According to this the number of education sets to be used in the activites should be increased and it should be ensured that the students have sufficient number of sets. These education sets should be supported with technologies such as 3D printers and students should be given the means to create their own designs. Also the test results indicate that the use of visual software in education has lead to an increase in students' interest and greater ease of building the program software.

With the educations from the meeting with the class teacher, it's been established that the use of technology in scientific activities has had positive affect on the students' motivation, that the students enjoy being closely connected with technology and that they wish to partake in robot design and programming activities.

\section{REFERENCE LIST}

Baş, H. ve Yapıcı F. (2015).Ergonomik Tasarım ve Üretimde Hızlı Protipleme Teknolojisi. Süleyman Demirel Üniversitesi Mühendislik Bilimleri ve Tasarım Dergisi, 3 (3).(in Turkish)

Bilim Şurası Raporu. (2003). Türkiye Bilişim Vakfı, Ankara. (in Turkish)

Çatlak, Ş. Tekdal, M. ve Çağatay Baz F. (2015). Scratch Yazııım İle Programlama Öğretiminin Durumu. Journal of Instructional Technologies \& Teacher Education, 3 (3).

Çelik, İ. Karakoç, F. Cemal, M. Duysak, A. (2013). Hızlı Protipleme Teknolojileri ve Uygulama Alanları. Fen bilimler Enstitüsü Dergisi, 31. (in Turkish)

Erbaş, S. K., (2014). Temel Robotik Uygulamalar ve Bilgisayar Destekli Tasarım Eğitimdeki Yeri. Eğitim ve Öğretim Araştırmaları Dergisi, 3 (3). (in Turkish)

Goh H. F., Aris B. (2007). Using Robotics İn Education: Lessons Learned and Learning Experiences. International Malaysian Educational Technology Convention, University Technology Malaysia, 1.

Koç, Ş. A., Robotik Destekli Fen ve Teknoloji Laboratuvar Uygulamaları: Robolab. Erciyes Üniversitesi Eğitim Bilimleri Enstitüsü Yüksek Lisans Tezi, Haziran 2012 (in Turkish)

Marulcu, A. (2014). 6. Ve 7. Sınıf Öğrenciler İçin Gerçekleştirilen "Küçük Bilginler Bilim Okulu" nun Değerlendirilmesi. Mustafa Kemal Üniversitesi Sosyal Bilimler Enstitüsü Dergisi, 25 (in Turkish)

Pınar, C. Kalıpsız O. (2015). Öğrenci Proje Anketlerini Sınıflandırmada En Başarılı Algoritmanın Belirlenmesi, TBV - Türkiye Bilişim Vakfı Bilgisayar Bilimleri ve Mühendisliği Dergisi, 1, (in Turkish) 